\title{
Effects of timing of palmitic acid supplementation on production responses of early-lactation dairy cows
}

\author{
J. de Souza and A. L. Lock* \\ Department of Animal Science, Michigan State University, East Lansing 48824
}

\begin{abstract}
The objective of our study was to evaluate the effects of timing of palmitic acid (C16:0) supplementation on production responses of early-lactation dairy cows. Fifty-two multiparous cows were used in a randomized complete block design experiment. During the fresh period (FR; 1-24 d in milk) cows were assigned to either a control diet containing no supplemental fat $(\mathrm{CON})$ or a diet supplemented with C16:0 (palmitic acid, PA; $1.5 \%$ of diet dry matter). During the peak (PK) period (25-67 d in milk) cows were assigned to either a CON diet or a PA (1.5\% of diet dry matter) diet in a $2 \times$ 2 factorial arrangement of treatments considering the diet that they received during the FR period. During the FR period, we did not observe treatment differences for dry matter intake or milk yield. Compared with CON, PA increased the yield of $3.5 \%$ fat-corrected milk by $5.30 \mathrm{~kg} / \mathrm{d}$, yield of energy-corrected milk (ECM) by $4.70 \mathrm{~kg} / \mathrm{d}$, milk fat content by $0.41 \%$ units, milk fat yield by $280 \mathrm{~g} / \mathrm{d}$, and protein yield by $100 \mathrm{~g} / \mathrm{d}$. The increase in milk fat associated with the PA treatment during the FR period occurred due to an increase in yield of 16-carbon milk fatty acids (FA) by $147 \mathrm{~g} / \mathrm{d}$ (derived from both de novo synthesis and extraction from plasma) and preformed milk FA by $96 \mathrm{~g} / \mathrm{d}$. Compared with CON, PA decreased body weight (BW) by $21 \mathrm{~kg}$ and body condition score (BCS) by 0.09 units and tended to increase BW loss by $0.76 \mathrm{~kg} / \mathrm{d}$. Although PA consistently increased milk fat yield and ECM over time, a treatment $\times$ time interaction was observed for $\mathrm{BW}$ and $\mathrm{BCS}$ due to $\mathrm{PA}$ inducing a greater decrease in BW and BCS after the second week of treatments. Feeding PA during the PK period increased milk yield by $3.45 \mathrm{~kg} / \mathrm{d}$, yield of $3.5 \%$ fat-corrected milk by 4.50 $\mathrm{kg} / \mathrm{d}$, yield of ECM by $4.60 \mathrm{~kg} / \mathrm{d}$, milk fat content by $0.22 \%$ units, milk fat yield by $210 \mathrm{~g} / \mathrm{d}$, protein yield by $140 \mathrm{~g} / \mathrm{d}$, and lactose yield by $100 \mathrm{~g} / \mathrm{d}$ but tended to reduce $\mathrm{BW}$ by $10 \mathrm{~kg}$ compared with CON. Also, during
\end{abstract}

Received April 26, 2018.

Accepted September 10, 2018.

*Corresponding author: allock@msu.edu the PK period we observed an interaction between diet fed in the FR and PK periods for milk fat yield due to feeding PA during the PK period increasing milk fat yield to a greater extent in cows that received the CON $\operatorname{diet}(+240 \mathrm{~g} / \mathrm{d})$ rather than the PA diet $(+180 \mathrm{~g} / \mathrm{d})$ during the FR period. This difference was associated with the yield of preformed FA because feeding PA during the PK period increased the yield of preformed milk FA only in cows that received the CON diet during the FR period. In conclusion, feeding a C16:0 supplement to early-lactation cows consistently increased the yield of ECM in both the FR and PK periods compared with a control diet. For some variables, the effect of feeding C16:0 was affected by timing of supplementation because milk yield increased only during the PK period and BW decreased to a greater extent in the FR period. Regardless of diet fed in the FR period, feeding a C16:0 supplement during the PK period increased yields of milk and milk components.

Key words: palmitic acid, early lactation, fat supplementation, milk fat

\section{INTRODUCTION}

The high metabolic demand of lactation and reduced DMI during the immediate postpartum period result in a state of negative energy balance in dairy cows (NRC, 2001). Approaches to increase energy intake of postpartum cows include increasing dietary starch content and supplementing fat to increase the energy density of the diet (McCarthy et al., 2015; Piantoni et al., 2015b). However, feeding high-starch diets that promote greater ruminal propionate production during early lactation could be hypophagic and therefore further reduce DMI and increase the risk of ruminal acidosis and displaced abomasum (Allen et al., 2009; Allen and Piantoni, 2013). Some authors suggest that caution should be exercised when using supplemental fats to increase the caloric density of diets in early-lactation dairy cows because a high lipid load may affect the endocrine system and feed intake and increase the risk for metabolic disorders (Kuhla et al., 2016). However, we are increasing our understanding of the effects of 
different fatty acids (FA) on metabolism and animal responses. For example, UFA can depress feed intake (Allen, 2000), increase plasma insulin (de Souza et al., 2018), alter ruminal biohydrogenation, and increase energy partitioning to body reserves (Harvatine et al., 2009; de Souza et al., 2018), whereas SFA have little effect on DMI (Allen, 2000) and can increase milk energy output (Lock et al., 2013; de Souza and Lock, 2018). Hence, determining dairy cow responses to specific FA may allow for more precise recommendations.

In general, fat supplementation has been shown to increase milk yield (Rabiee et al., 2012) and reproductive performance (Rodney et al., 2015), but great variation has been reported for different fat types and even the same supplement across different diets and studies. Although most commercially available FA supplements have typically contained mixtures of different FA, supplements enriched with individual FA are becoming increasingly available. Determining the effects of individual FA on production responses and metabolism of lactating dairy cows is therefore important. Recently, considerable research has focused on palmitic acid (C16:0) because of its potential to increase milk fat concentration and yield and the efficiency of milk production compared with a control diet (Lock et al., 2013; de Souza et al., 2017) and with other FA supplements (Rico et al., 2014a,b; de Souza et al., 2018). However, to our knowledge, our research and work by others with C16:0 has evaluated production and metabolic responses of postpeak cows. Thus, this raises a question about the response of early-lactation cows to C16:0 supplements and when these supplements should be fed.

In early-lactation cows, previous studies suggest that the response to FA supplementation may vary due to the timing when supplemental FA are fed. Of particular importance, Piantoni et al. (2015b) fed a SFA supplement (C16:0 + C18:0) and observed that FA supplementation during the immediate postpartum period (1-29 DIM) favored energy partitioning to body reserves rather than milk yield, especially in a reducedforage diet. The high-forage diet with supplemental FA increased DMI and tended to decrease BCS loss compared with the same diet without FA supplementation. However, Weiss and Pinos-Rodríguez (2009) fed a similar FA supplement (C16:0 + C18:0) to early-lactation cows (21-126 d postpartum) and observed that when diets were supplemented with FA, energy intake was increased and directed mostly to milk production in a lower forage diet and to body reserves in a higher forage diet. Interestingly, these results suggest that energy partitioning due to FA supplementation is affected differently according to the timing of supplementation.
Although these results suggest a positive effect of FA supplementation on production responses of earlylactation dairy cows, it is possible that the magnitude of response may vary not only due to the FA profile but also to the timing when the supplement is fed.

Therefore, the objective of our study was to evaluate the effects of timing of C16:0 supplementation on production responses of early-lactation dairy cows. We hypothesized that feeding a C16:0 supplement would increase milk yield and milk fat yield in early-lactation cows but that production responses to supplemental C16:0 would be greater if the supplementation starts after the fresh period ( $\sim 3$ wk after parturition).

\section{MATERIALS AND METHODS}

\section{Animal Housing and Care}

This is the first paper from an experiment that evaluated the effects of timing of C16:0 supplementation on performance and metabolism of early-lactation cows. This paper describes the effect of these diets on DMI, yield of milk and milk components, and milk FA profile. The companion paper (de Souza et al., 2019) describes treatment effects on nutrient digestibility, energy intake and balance, and plasma metabolites and hormones.

All experimental procedures were approved by the Institutional Animal Care and Use Committee at Michigan State University (East Lansing). The experiment began on December 18, 2015, and ended on August 4, 2016. Cows were fed once daily $(9000 \mathrm{~h})$ at 120 and $110 \%$ of expected intake during the fresh (FR) and peak $(\mathbf{P K})$ periods, respectively, and milked twice daily $(0400$ and $1430 \mathrm{~h})$. The amounts of feed offered and orts were weighed for each cow daily. Standard reproduction and health herd checks and breeding practices were maintained during this study.

\section{Design and Treatment Diets}

Fifty-two multiparous Holstein cows at the Michigan State University Dairy Field Laboratory were used in a randomized complete block design experiment with a $2 \times 2$ factorial arrangement of treatments. Cows were blocked by BCS (up to 0.50-unit difference using the scale of $1=$ thin and $5=$ fat in 0.25 increments), previous lactation 305-d mature-equivalent yield (within $1,500 \mathrm{~kg}$ ), and parity (up to 1 lactation difference). The BCS used to block cows was the last measurement before parturition. During the FR period (1-24 DIM) cows were assigned to either a control diet containing no supplemental fat $(\mathbf{C O N})$ or a $\mathrm{C} 16: 0$-supplemented diet (PA; $1.5 \%$ of diet DM). During the PK period 
(25-67 DIM) cows were assigned to either a CON diet or a PA diet $(1.5 \%$ of diet DM) in a $2 \times 2$ factorial arrangement of treatments considering the diet that they received during the FR period. The FR and PK diets fed were adjusted for fiber, CP, and starch levels as well as starch fermentability. The FA supplement was added at $1.5 \%$ of diet DM, replacing $1.5 \%$ of soyhulls in the control diet. Treatment diets were mixed daily in a tumble mixer and were fed from the morning following parturition. The ingredient and nutrient composition of the diets fed as TMR, including the close-up ration for reference, are described in Table 1. All rations were formulated to meet or exceed cows' predicted requirements for minerals and vitamins according to NRC (2001).

\section{Data and Sample Collection}

All samples and body measurements were collected or recorded on the same day of the week during the entire experiment, so all collection days are $\pm 3 \mathrm{~d}$. Daily milk yield and feed offered and refused were recorded

Table 1. Ingredient and nutrient composition of close-up and treatment diets

\begin{tabular}{|c|c|c|c|c|c|}
\hline \multirow{2}{*}{ Item } & \multirow{2}{*}{ Close-up } & \multicolumn{4}{|c|}{ Diet $^{1}$} \\
\hline & & \multicolumn{2}{|c|}{ FR } & \multicolumn{2}{|c|}{ PK } \\
\hline \multicolumn{6}{|l|}{ Ingredient, $\%$ of DM } \\
\hline Corn silage & 34.2 & 27.5 & 27.5 & 26.4 & 26.4 \\
\hline Alfafa silage & - & 12.9 & 12.9 & 16.4 & 16.4 \\
\hline Wheat straw & - & - & - & 2.76 & 2.76 \\
\hline Ground corn & 9.59 & 18.6 & 18.6 & 13.9 & 13.9 \\
\hline High-moisture corn & - & 6.49 & 6.49 & 13.5 & 13.5 \\
\hline Soybean meal & 13.2 & 12.8 & 12.8 & 12.4 & 12.4 \\
\hline Soyhulls & - & 2.82 & 1.36 & 5.57 & 4.06 \\
\hline Whole cottonseed & - & 3.50 & 3.50 & 5.49 & 5.49 \\
\hline Palmitic acid supplement ${ }^{2}$ & - & - & 1.46 & - & 1.51 \\
\hline Starch & $15.5 \pm 0.44$ & $23.5 \pm 0.65$ & $23.5 \pm 0.65$ & $27.4 \pm 0.72$ & $27.4 \pm 0.72$ \\
\hline Gross energy, Mcal/kg of DM & - & $4.49 \pm 0.11$ & $4.61 \pm 0.12$ & $4.97 \pm 0.15$ & $5.05 \pm 0.17$ \\
\hline $\mathrm{NE}_{\mathrm{L}},{ }^{7} \mathrm{Mcal} / \mathrm{kg}$ of DM & - & $1.51 \pm 0.02$ & $1.63 \pm 0.02$ & $1.55 \pm 0.02$ & $1.67 \pm 0.02$ \\
\hline Fatty acids & $1.82 \pm 0.05$ & $2.99 \pm 0.06$ & $4.48 \pm 0.10$ & $3.55 \pm 0.08$ & $5.07 \pm 0.12$ \\
\hline $16: 0$ & $0.23 \pm 0.01$ & $0.47 \pm 0.02$ & $1.72 \pm 0.06$ & $0.61 \pm 0.02$ & $1.84 \pm 0.06$ \\
\hline 18:0 & $0.06 \pm 0.001$ & $0.08 \pm 0.002$ & $0.18 \pm 0.01$ & $0.13 \pm 0.008$ & $0.23 \pm 0.01$ \\
\hline cis-9 18:1 & $0.30 \pm 0.01$ & $0.54 \pm 0.02$ & $0.68 \pm 0.02$ & $0.65 \pm 0.02$ & $0.79 \pm 0.03$ \\
\hline cis-9,cis-12 18:2 & $0.76 \pm 0.03$ & $1.48 \pm 0.05$ & $1.52 \pm 0.05$ & $1.79 \pm 0.07$ & $1.81 \pm 0.07$ \\
\hline cis-9,cis-12,cis-15 18:3 & $0.05 \pm 0.001$ & $0.17 \pm 0.01$ & $0.18 \pm 0.01$ & $0.21 \pm 0.01$ & $0.21 \pm 0.01$ \\
\hline
\end{tabular}

${ }^{1}$ Close-up diet was fed from $\mathrm{d}-21$ of expected calving date until calving. Diets fed during the fresh (FR) period (1-24 DIM) were either a control $\operatorname{diet}(\mathrm{CON})$ or a diet supplemented with C16:0-enriched fatty acid supplement replacing soyhulls (PA; $1.5 \%$ of diet DM). Diets fed during the peak (PK) period (25-67 DIM) were either CON or PA.

${ }^{2}$ C16:0-enriched fatty acid supplement (Palmit 80, Global Agri-Trade Corporation, Rancho Dominguez, CA). The supplement contained (g/100 $\mathrm{g}$ of fatty acids) 1.0 of $\mathrm{C} 14: 0,85.1$ of $\mathrm{C} 16: 0,2.7$ of $\mathrm{C} 18: 0$, and 8.9 of cis-9 $\mathrm{C} 18: 1$; and $99.0 \%$ total fatty acids.

${ }^{3}$ Vitamin-mineral mix for the close-up diet contained (DM basis) 54.8\% SoyChlor (Landus Cooperative, Ralston, IA), $13.9 \%$ limestone, $10.0 \%$ rumen-protected choline (Balchem Inc., New Hampton, NY), $8.8 \%$ dicalcium phosphate, $4.2 \%$ magnesium sulfate, $1.8 \%$ salt, $1.8 \%$ yeast, $4.4 \%$ trace minerals and vitamins, $0.3 \%$ selenium yeast $600(600 \mathrm{mg}$ of Se $/ \mathrm{kg})$, and $0.09 \%$ Smartamine (Adisseo NA, Alpharetta, GA).

${ }^{4}$ Vitamin-mineral mix for the FR diets contained (DM basis) $27.9 \%$ molasses, $15.3 \%$ limestone, $12.2 \%$ sodium bicarbonate, $11.8 \%$ blood meal, $8.7 \%$ dicalcium phosphate, $6.1 \%$ trace minerals and vitamins, $5.7 \%$ rumen-protected choline (Balchem Inc., New Hampton, NY), $4.4 \%$ magnesium sulfate, $3.9 \%$ salt, $2.7 \%$ animal fat, $0.9 \%$ yeast, $0.4 \%$ selenium yeast 600 (600 $\mathrm{mg}$ of Se/kg), and $0.09 \%$ Smartamine (Adisseo NA).

${ }^{5}$ Vitamin-mineral mix for the PK diet contained (DM basis) $30.1 \%$ limestone, $25.3 \%$ sodium bicarbonate, $10.1 \%$ salt, $7.1 \%$ urea, $6 \%$ potassium chloride, $6 \%$ dicalcium phosphate, $5.7 \%$ animal fat, $5.7 \%$ magnesium sulfate, $3.9 \%$ trace minerals and vitamins, $0.2 \%$ selenium yeast 600 (600 $\mathrm{mg}$ of $\mathrm{Se} / \mathrm{kg}$ ), and $0.09 \%$ Smartamine (Adisseo NA).

${ }^{6}$ Mean \pm SD of samples analyzed monthly $(\mathrm{n}=7)$.

${ }^{7}$ Calculated $\mathrm{NE}_{\mathrm{L}}$ using nutrient digestibility values as presented in de Souza et al. (2019). 
daily throughout the experiment. Samples of all diet ingredients $(0.5 \mathrm{~kg})$ and orts from each cow $(\sim 12.5 \%)$ were collected weekly during the experiment and stored in plastic bags at $-20^{\circ} \mathrm{C}$ until processed. Milk samples were collected twice a week at each milking and stored with preservative at $4^{\circ} \mathrm{C}$ for component analysis. An additional milk sample was collected at each milking on d 5, 12, 19, 33, 47, and 61 postpartum and stored without preservative at $-20^{\circ} \mathrm{C}$ for determination of $\mathrm{FA}$ profile. Body weight was recorded 3 times per week from $\mathrm{d}-21$ of expected parturition and throughout the experiment. Body condition was scored weekly by 3 trained investigators on a 5 -point scale, where $1=$ thin and $5=$ fat, as described by Wildman et al. (1982).

\section{Sample Analysis}

Feed and orts samples were dried in a $55^{\circ} \mathrm{C}$ forced-air oven for $72 \mathrm{~h}$ and analyzed for DM content. Before drying, ingredients were composited monthly. Orts were dried to calculate DMI weekly, but only orts collected on d $5,12,19,33,47$, and 61 postpartum were processed further and analyzed for nutrient composition. Once dried, samples of feed ingredients and orts collected were ground in a Wiley mill (1-mm screen; Arthur H. Thomas Co., Philadelphia, PA) and analyzed for ash, NDF, indigestible NDF, CP, starch, and FA concentration as described by Boerman et al. (2017).

Milk samples were analyzed for fat, true protein, and lactose concentrations by mid-infrared spectroscopy (AOAC, 1990; method 972.160; Universal Lab Services, Lansing, MI). Yields of 3.5\% FCM, ECM, milk energy, and milk components were calculated using milk yield and component concentrations from each milking, summed for a daily total, and averaged for each week. Milk samples stored without preservative were composited daily by milk fat yield and centrifuged at $17,800 \times$ $g$ for 30 min at $4^{\circ} \mathrm{C}$ to collect the fat cake. Milk lipids were extracted, and FAME were prepared and quantified using GLC according to Lock et al. (2013). Yield of individual FA (g/d) in milk fat was calculated by using milk fat yield and FA concentration to determine yield on a mass basis using the molecular weight of each FA while correcting for glycerol content and other milk lipid classes (Piantoni et al., 2013).

\section{Statistical Analysis}

Data were analyzed separately for FR (from 1 to $24 \mathrm{~d}$ postpartum) and PK (from 25 to $67 \mathrm{~d}$ postpartum) periods. All weekly data were analyzed using the MIXED procedure of SAS version 9.2 (SAS Institute Inc., Cary, $\mathrm{NC)}$ with repeated measures.

For the FR period, the model used included

$$
\begin{aligned}
\mathrm{Y}_{\mathrm{ijklm}}= & \mu+\mathrm{B}_{\mathrm{i}}+\mathrm{C}\left(\mathrm{B}_{\mathrm{i}} \mathrm{F}_{\mathrm{k}}\right)_{\mathrm{j}}+\mathrm{F}_{\mathrm{k}}+\mathrm{T}_{\mathrm{l}} \\
& +\mathrm{J}_{\mathrm{m}}+\mathrm{F}_{\mathrm{k}} \mathrm{T}_{1}+\mathrm{e}_{\mathrm{ijklm}},
\end{aligned}
$$

where $Y_{i j k l m}$ is the dependent variable, $\mu=$ overall mean, $\mathrm{B}_{\mathrm{i}}=$ random effect of block, $\mathrm{C}\left(\mathrm{B}_{\mathrm{i}} \mathrm{F}_{\mathrm{k}}\right)_{\mathrm{j}}=$ random effect of cow within block and treatment diet, $\mathrm{F}_{\mathrm{k}}=$ fixed effect of treatment during the fresh period, $\mathrm{T}_{1}=$ fixed effect of time, $\mathrm{J}_{\mathrm{m}}=$ random effect of Julian date, $\mathrm{F}_{\mathrm{k}} \mathrm{T}_{1}=$ fixed effect of the interaction between treatment during the fresh period and time, and $\mathrm{e}_{\mathrm{ijk} k \mathrm{~m}}=$ residual error.

For the PK period, the model used included

$$
\begin{aligned}
& \mathrm{Y}_{\mathrm{ijklmn}}=\mu+\mathrm{B}_{\mathrm{i}}+\mathrm{C}\left(\mathrm{B}_{\mathrm{i}} \mathrm{F}_{\mathrm{k}} \mathrm{L}_{\mathrm{l}}\right)_{\mathrm{j}}+\mathrm{F}_{\mathrm{k}}+\mathrm{L}_{\mathrm{l}}+\mathrm{F}_{\mathrm{k}} \mathrm{L}_{\mathrm{l}} \\
& +\mathrm{T}_{\mathrm{m}}+\mathrm{J}_{\mathrm{n}}+\mathrm{F}_{\mathrm{k}} \mathrm{T}_{\mathrm{m}}+\mathrm{L}_{\mathrm{l}} \mathrm{T}_{\mathrm{m}}+\mathrm{F}_{\mathrm{k}} \mathrm{L}_{\mathrm{l}} \mathrm{T}_{\mathrm{m}}+\mathrm{e}_{\mathrm{ijk} \mathrm{k} m n},
\end{aligned}
$$

where $\mathrm{Y}_{\mathrm{ijk} k \mathrm{mn}}$ is the dependent variable, $\mu=$ overall mean, $\mathrm{B}_{\mathrm{i}}=$ random effect of block, $\mathrm{C}\left(\mathrm{B}_{\mathrm{i}} \mathrm{F}_{\mathrm{k}} \mathrm{L}_{1}\right)_{\mathrm{j}}=$ random effect of cow within block and treatment diet, $\mathrm{F}_{\mathrm{k}}$ $=$ fixed effect of treatment during the fresh period, $\mathrm{L}_{1}=$ fixed effect of treatment during the peak period, $\mathrm{F}_{\mathrm{k}} \mathrm{L}_{\mathrm{l}}=$ fixed effect of the interaction between treatment during the fresh period and treatment during the peak period, $\mathrm{T}_{\mathrm{m}}=$ fixed effect of time, $\mathrm{J}_{\mathrm{n}}=$ random effect of Julian date, $\mathrm{F}_{\mathrm{k}} \mathrm{T}_{\mathrm{m}}=$ fixed effect of the interaction between treatment during the fresh period and time, $\mathrm{L}_{1} \mathrm{~T}_{\mathrm{m}}=$ fixed effect of the interaction between treatment during the peak period and time, $\mathrm{F}_{\mathrm{k}} \mathrm{L}_{\mathrm{l}} \mathrm{T}_{\mathrm{m}}=$ fixed effect of the interaction between treatment during the fresh and peak periods and time, and $\mathrm{e}_{\mathrm{ijklmn}}=$ residual error.

Unless otherwise specified, first-order autoregressive was the covariate structure used for analysis because it resulted in the lowest Bayesian information criterion for most of the variables measured. Precalving BCS and BW were used as covariates for BW, BCS, BW change, and BCS change. Normality of the residuals was checked with normal probability and box plots and homogeneity of variances with plots of residuals versus predicted values. Significance was declared at $P \leq 0.05$ for main effects and $P \leq 0.10$ for interactions. Tendencies were declared at $P \leq 0.10$ for main effects and $P$ $\leq 0.15$ for interactions. When interactions were at $P$ $\leq 0.15$, the slice option was used to evaluate treatment effects within time, or the effect of PK treatments within FR treatments, and the Bonferroni adjustment was applied to decrease the probability of type I error. All cows were in apparent good health at the beginning of the study, and treatment groups were not different in terms of 305-d mature-equivalent yield $(P=0.79)$, BW $(P=0.84)$, or BCS $(P=0.43)$ precalving. Two cows (1 CON and $1 \mathrm{PA}$ ) had a displaced abomasum and underwent surgery and were excluded from the statistical analyses. 


\section{RESULTS}

\section{Diets and Nutrient Composition,} and Health Incidents

Ingredient and nutrient composition of close-up and treatment diets are shown in Table 1 . All cows received the same close-up diet before calving. Compared with the FR period, during the PK period, diets were adjusted to reduce forage and increase starch content and fermentability. In both the FR and PK periods, PA diets mainly increased dietary $\mathrm{C} 16: 0$, and a slight increase in dietary C18:0 and cis-9 C18:1 was observed compared with CON.

This study was not designed to evaluate treatment effects on health incidents. Therefore, only a summary of health incidents is presented in Table 2. Retained placenta was the major health incident observed, with 5 and 4 cases detected for CON and PA, respectively, and with 6 out of 9 cases occurring in cows that calved during the summer. During the FR period, we observed 4 and 5 cases of ketosis for CON and PA, respectively, whereas no incidents were detected during the PK period. The major health incident during the PK period was mastitis, with 1 and 2 cases for CON and PA, respectively.

\section{Production Responses During FR}

Dry matter intake and milk yield increased over time for both treatments (Figure 1A and B), but we did not observe treatment differences for DMI $(P=0.92$; Table
$3)$ or milk yield $(P=0.39)$. Compared with $\mathrm{CON}, \mathrm{PA}$ increased the yield of $3.5 \% \mathrm{FCM}$ by $5.30 \mathrm{~kg} / \mathrm{d}(P<$ $0.01)$ and the yield of ECM by $4.70 \mathrm{~kg} / \mathrm{d}(P<0.01)$. The increase in ECM was consistent over time (Figure $1 \mathrm{C})$. The PA treatment increased milk fat content by 0.41 percentage unit $(P=0.01)$, milk fat yield by 280 $\mathrm{g} / \mathrm{d}(P<0.01)$, protein yield by $100 \mathrm{~g} / \mathrm{d}(P=0.03)$, and feed efficiency $(P<0.01)$ compared with CON. We did not observe treatment differences for milk protein content $(P=0.65)$, milk lactose content $(P=0.46)$, or milk lactose yield $(P=0.43)$. Although cumulative milk yield did not differ between treatments $(P=0.25)$, PA increased cumulative yield of milk fat $(P<0.01)$ and protein $(P=0.05)$ compared with CON. Compared with CON, PA reduced BW by $21 \mathrm{~kg}(P=0.05)$ and BCS by 0.09 unit $(P=0.04)$ and tended to increase BW loss by $0.76 \mathrm{~kg} / \mathrm{d}(P=0.07)$. The PA treatment consistently increased milk fat yield over time (Figure $2 \mathrm{~A})$, and a treatment $\times$ time interaction was observed for BW $(P=0.05)$ and $\mathrm{BCS}(P=0.07)$ due to PA inducing a greater decrease in BW and BCS over time (Figure 2B and $\mathrm{C}$ ).

\section{Production Responses During PK}

Feeding PA during the PK period increased the yield of milk by $3.45 \mathrm{~kg} / \mathrm{d}(P=0.01$; Table 4$)$, the yield of $3.5 \% \mathrm{FCM}$ by $4.50 \mathrm{~kg} / \mathrm{d}(P<0.01)$, and the yield of ECM by $4.60 \mathrm{~kg} / \mathrm{d}(P<0.01)$ compared with CON. We did not observe treatment differences for DMI $(P=$ $0.68)$, milk protein content $(P=0.22)$, or milk lactose content $(P=0.43)$. The increase in milk yield and ECM

Table 2. Health incidents during the experiment within treatment diet

\begin{tabular}{|c|c|c|c|c|}
\hline \multirow[b]{2}{*}{ Item } & \multicolumn{4}{|c|}{$\operatorname{Diet}^{1}$} \\
\hline & \multicolumn{2}{|c|}{$\mathrm{CON}$} & \multicolumn{2}{|c|}{ PA } \\
\hline \multicolumn{5}{|l|}{ During FR period } \\
\hline Fever with no apparent cause $\left(>39.5^{\circ} \mathrm{C}\right)$ & \multicolumn{2}{|c|}{1} & \multicolumn{2}{|c|}{0} \\
\hline Ketosis & \multicolumn{2}{|c|}{4} & \multicolumn{2}{|c|}{5} \\
\hline Lame & \multicolumn{2}{|c|}{0} & \multicolumn{2}{|c|}{0} \\
\hline Mastitis & \multicolumn{2}{|c|}{1} & \multicolumn{2}{|c|}{0} \\
\hline Metritis & \multicolumn{2}{|c|}{2} & \multicolumn{2}{|c|}{3} \\
\hline Milk fever & \multirow{2}{*}{\multicolumn{2}{|c|}{$\begin{array}{l}0 \\
5\end{array}$}} & \multirow{2}{*}{\multicolumn{2}{|c|}{$\begin{array}{l}0 \\
4\end{array}$}} \\
\hline Retained placenta & & & & \\
\hline \multirow[t]{2}{*}{ Displaced abomasum } & \multicolumn{2}{|c|}{1} & \multicolumn{2}{|c|}{0} \\
\hline & $\mathrm{CON}-\mathrm{CON}$ & CON-PA & PA-CON & PA-PA \\
\hline \multicolumn{5}{|l|}{ During PK period } \\
\hline Displaced abomasum & 0 & 0 & 0 & 1 \\
\hline Ketosis & 0 & 0 & 0 & 0 \\
\hline Lame & 0 & 0 & 1 & 0 \\
\hline Mastitis & 0 & 1 & 1 & 1 \\
\hline
\end{tabular}




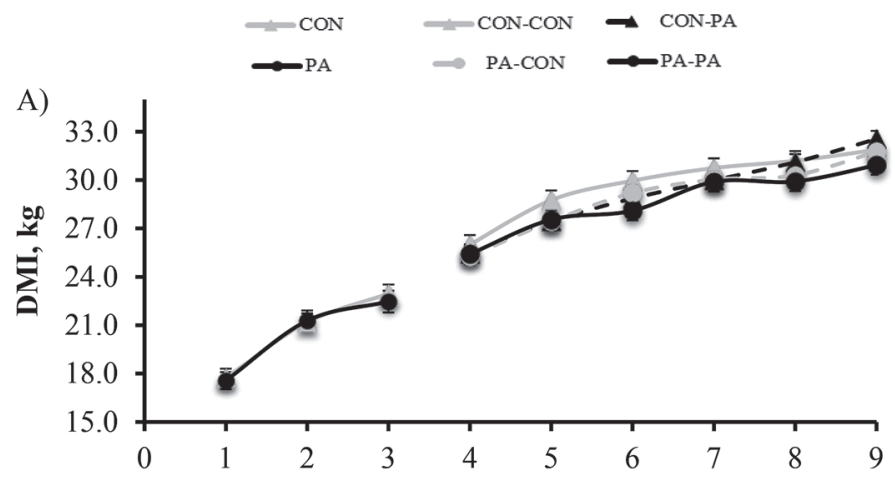

B)
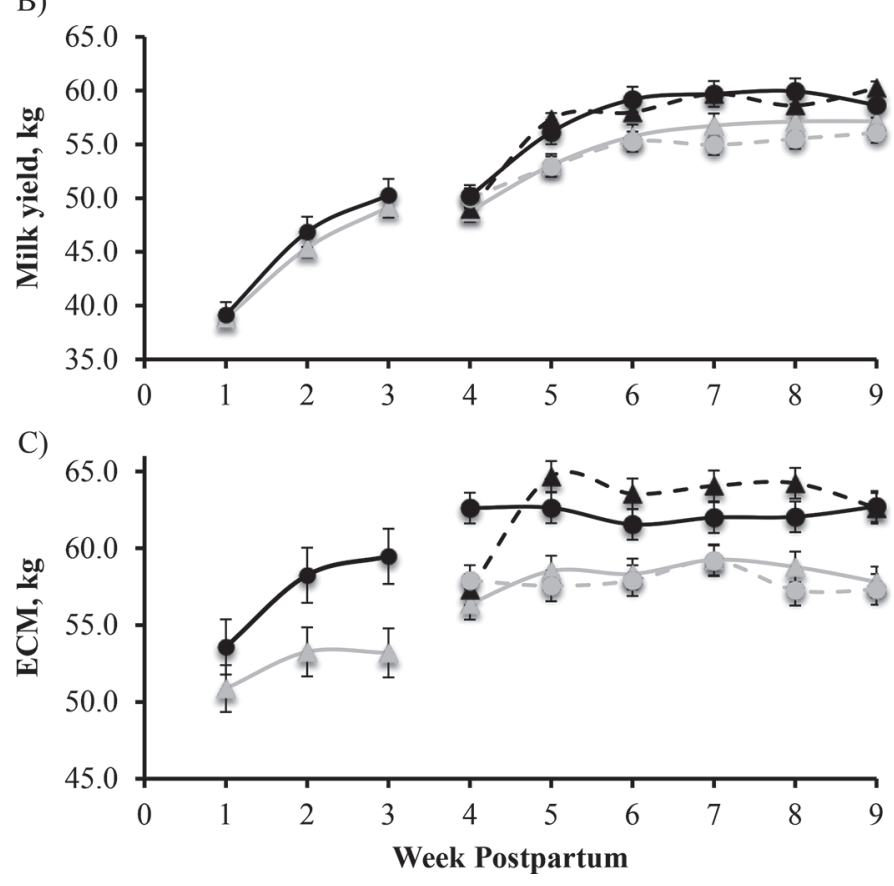

Figure 1. Effects of dietary treatments on DMI (A), milk yield (B), and ECM (C) over time during the fresh (FR) period (1-24 DIM) and peak (PK) period (25-67 DIM). Diets fed during the FR period were either a control (CON; gray line) or $1.5 \%$ of $\mathrm{C} 16: 0$-enriched supplement (PA; black line). During the PK period treatments were as follows: $\mathrm{CON}-\mathrm{CON}=$ cows received $\mathrm{CON}$ for both $\mathrm{FR}$ and $\mathrm{PK}$ periods (gray line); CON-PA $=$ cows received CON during $\mathrm{FR}$ and changed to the PA diet (1.5\% of C16:0-enriched supplement) during the $\mathrm{PK}$ period (black dashed line); $\mathrm{PA}-\mathrm{CON}=$ cows received the PA diet during the FR period and changed to the CON diet during the PK period (gray dashed line); PA-PA = cows received the PA diet for the FR and PK periods (black line). During the FR period, PA increased ECM $(P=0.02)$ and did not affect milk yield $(P=0.38)$ and DMI $(P$ $=0.92$ ) compared with CON. Dry matter intake, milk yield, and ECM increased over time in both treatments (all $P<0.01$ ), and we did not observe a treatment $\times$ time interaction for DMI $(P=0.91)$, milk yield $(P=0.61)$, and ECM $(P=0.63)$. During the PK period, PA increased milk yield $(P=0.01)$ and ECM $(P<0.01)$ and did not affect DMI $(P$ $=0.68)$ compared with CON. Dry matter intake, milk yield, and ECM increased over time in all treatments (all $P<0.01$ ), and we did not observe a treatment $\times$ time interaction for DMI $(P=0.79)$, milk yield $(P=0.31)$, and ECM $(P=0.46)$. Error bars indicate SEM. by PA was consistent over time (Figure $1 \mathrm{~B}$ and $\mathrm{C}$ ). The PA treatment increased milk fat content by 0.22 percentage unit $(P<0.01)$, milk fat yield by $210 \mathrm{~g} / \mathrm{d}$ $(P<0.01)$, milk protein yield by $140 \mathrm{~g} / \mathrm{d}(P=0.04)$, lactose yield by $100 \mathrm{~g} / \mathrm{d}(P=0.04)$, and feed efficiency $(P<0.01)$ compared with CON. The PA treatment increased cumulative yield of milk $(P<0.01)$, milk fat $(P<0.01)$, and milk protein $(P=0.05)$ compared with CON. In contrast, compared with $\mathrm{CON}$, PA reduced BCS by 0.10 unit $(P=0.05)$ and tended to reduce BW by $10 \mathrm{~kg}(P=0.06)$.

During the PK period, no treatment $\times$ time interactions were observed for all variables evaluated $(P>$ 0.15 ; Table 4). The interaction between diet fed during the FR and PK periods was also not significant for most variables evaluated $(P>0.15)$; however, feeding PA during the PK period increased milk fat yield to a greater extent in cows that received the $\mathrm{CON}$ diet during the FR period (interaction; $P=0.07$; Figure 2A).

During the PK period, the effect of diet fed during the FR period was not significant for most variables evaluated $(P>0.10$; Table 4$)$. In contrast, we observed that cows that received PA during the FR period had lower BW $(P=0.01)$ and tended to reduce BW change $(P=0.07)$ compared with cows that received CON during the FR period.

\section{Milk FA Concentration and Yield During FR}

Milk FA are derived from 2 sources: $<16$ carbon FA from de novo synthesis in the mammary gland and $>16$ carbon FA originating from extraction from plasma. Mixed-source FA (C16:0 and cis-9 C16:1) originate from de novo synthesis in the mammary gland and extraction from plasma. Compared with CON, PA did not affect de novo FA concentration $(P=0.23$; Table $5)$, tended to reduce preformed FA concentration $(P=$ $0.07)$, and increased mixed-source FA $(P<0.01)$. Compared with CON, PA increased milk FA concentration of C16:0 $(P<0.01$; Supplemental Table S1, https:// doi.org/10.3168/jds.2018-14976) but reduced the concentration of cis-9,cis-12,cis-15 C18:3 $(P=0.03)$. We observed an interaction between treatment and time for mixed-FA concentration $(P<0.01)$ due to PA increasing mixed-FA concentration over time compared with CON (data not shown). On a yield basis, PA increased mixed-source FA $(P<0.01$; Table 5$)$ primarily due to the increase in the yield of C16:0 $(P<0.01$; Supplemental Table S2, https://doi.org/10.3168/jds.2018 -14976). Compared with CON, PA did not affect the yield of de novo milk FA $(P=0.32)$ but increased the yield of C4:0 $(P=0.02)$. Additionally, compared with CON, PA increased the yield of preformed milk FA $(P$ $=0.05)$ mainly due to the increase in the yield of C18:0 
$(P=0.03 ;$ Supplemental Table S2, https://doi.org/10 $.3168 /$ jds.2018-14976) and cis-9 C18:1 $(P=0.05)$. We observed a tendency for an interaction between treatment and time for mixed-FA yield $(P=0.12)$ due to PA increasing mixed-FA yield over time compared with CON (Figure 3).

\section{Milk FA Concentration and Yield During PK}

During the PK period, PA reduced de novo FA concentration $(P<0.01$; Table 6$)$, tended to reduce preformed FA concentration $(P=0.08)$, and increased mixed-source FA concentration $(P<0.01)$ compared with CON. Compared with CON, PA decreased milk FA concentration of C6:0, C8:0, C10:0, C12:0 C14:0, C18:0, cis-9,cis-12 C18:2, and cis-9,cis-12,cis-15 C18:3 (all $P<0.05$; Supplemental Table S3, https://doi.org/ 10.3168/jds.2018-14976) but increased the concentration of C16:0 $(P<0.01)$. On a yield basis, PA increased mixed-source FA $(P<0.01$; Table 6$)$ primarily due to the increase in the yield of C16:0 $(P<0.01$; Supplemental Table S4, https://doi.org/10.3168/jds.2018-14976). In contrast, PA did not affect the yield of de novo milk FA $(P=0.54)$ or preformed milk FA $(P=0.72)$. Additionally, PA tended to increase the yield of $\mathrm{C} 4: 0(P=$
0.10; Supplemental Table S4, https://doi.org/10.3168/ jds.2018-14976) compared with CON.

We observed a tendency for an interaction between the diet fed at PK and time for de novo FA yield $(P$ $=0.03$; Table 6 ) due to PA reducing de novo FA yield compared with CON at wk 7 but not at wk 5 and 9 (Figure 3). The interaction between diet fed during the FR and PK periods was not significant for the concentration and yield of most FA evaluated $(P>0.15$; Table 6). However, feeding PA during the PK period increased the concentration of mixed milk FA to a greater extent in cows that received the PA diet during the FR period (interaction; $P=0.08$ ). Also, feeding PA during the PK period increased the yield of preformed milk FA only in cows that received the CON diet during the FR period (interaction; $P=0.06$ ).

\section{DISCUSSION}

The challenge of meeting nutrient requirements is greater during early lactation, when cows generally enter a period of negative energy and nutrient balance (NRC, 2001). Supplemental fat can be used to increase the energy density of diets and energy intake but usually does not improve energy balance (Moallem et al.,

Table 3. Milk production, milk composition, BW, and BCS for cows fed treatment diets during the fresh period (d 1-24 postpartum)

\begin{tabular}{|c|c|c|c|c|c|c|}
\hline \multirow[b]{2}{*}{ Variable } & \multicolumn{2}{|c|}{ Treatment $^{1}$} & \multirow[b]{2}{*}{ SEM } & \multicolumn{3}{|c|}{$P$-value ${ }^{2}$} \\
\hline & $\mathrm{CON}$ & PA & & Trt & Time & Trt $\times$ time \\
\hline DMI, $\mathrm{kg} / \mathrm{d}$ & 22.3 & 22.1 & 0.62 & 0.92 & $<0.01$ & 0.91 \\
\hline \multicolumn{7}{|l|}{ Milk yield, $\mathrm{kg} / \mathrm{d}$} \\
\hline Milk & 47.2 & 48.6 & 1.05 & 0.39 & $<0.01$ & 0.61 \\
\hline $3.5 \% \mathrm{FCM}^{3}$ & 52.2 & 57.5 & 1.65 & 0.01 & $<0.01$ & 0.19 \\
\hline $\mathrm{ECM}^{4}$ & 51.9 & 56.6 & 1.46 & 0.02 & $<0.01$ & 0.17 \\
\hline \multicolumn{7}{|l|}{ Milk composition } \\
\hline Fat, kg/d & 2.01 & 2.29 & 0.08 & $<0.01$ & $<0.01$ & 0.59 \\
\hline Fat, $\%$ & 4.48 & 4.89 & 0.13 & 0.01 & $<0.01$ & 0.32 \\
\hline Protein, $\mathrm{kg} / \mathrm{d}$ & 1.50 & 1.60 & 0.04 & 0.03 & $<0.01$ & 0.25 \\
\hline Protein, \% & 3.37 & 3.41 & 0.06 & 0.65 & $<0.01$ & 0.21 \\
\hline Lactose, $\mathrm{kg} / \mathrm{d}$ & 2.16 & 2.23 & 0.05 & 0.43 & $<0.01$ & 0.32 \\
\hline Lactose, $\%$ & 4.75 & 4.72 & 0.02 & 0.46 & $<0.01$ & 0.22 \\
\hline \multicolumn{7}{|c|}{ Cumulative yield, $\mathrm{kg}$} \\
\hline Milk & 1,111 & 1,145 & 33.4 & 0.25 & $\mathrm{NA}^{5}$ & NA \\
\hline Fat & 49.8 & 56.0 & 0.94 & $<0.01$ & NA & NA \\
\hline Protein & 36.7 & 38.6 & 0.86 & 0.05 & NA & NA \\
\hline ECM/DMI & 2.34 & 2.60 & 0.08 & $<0.01$ & 0.58 & 0.54 \\
\hline $\mathrm{BW}, \mathrm{kg}$ & 701 & 680 & 11.8 & 0.05 & $<0.01$ & 0.05 \\
\hline BW change, $\mathrm{kg} / \mathrm{d}$ & -1.89 & -2.65 & 0.34 & 0.07 & NA & NA \\
\hline BCS & 3.34 & 3.25 & 0.06 & 0.04 & $<0.01$ & 0.07 \\
\hline
\end{tabular}

${ }^{1}$ Diets fed during the fresh (FR) period (1-24 DIM) were either a control diet (CON) or a diet supplemented with C16:0-enriched fatty acid supplement replacing soyhulls (PA; $1.5 \%$ of diet DM).

${ }^{2} P$-values refer to the ANOVA results for the main effect of treatment (Trt), the main effect of time, and the interaction between treatment and time.

${ }^{3} 3.5 \% \mathrm{FCM}=(0.4324 \times \mathrm{kg}$ of milk $)+(16.216 \times \mathrm{kg}$ milk of fat $)$.

${ }^{4} \mathrm{ECM}=(0.327 \times \mathrm{kg}$ of milk $)+(12.95 \times \mathrm{kg}$ of milk fat $)+(7.20 \times \mathrm{kg}$ of milk protein $)$.

${ }^{5}$ Not applicable. 


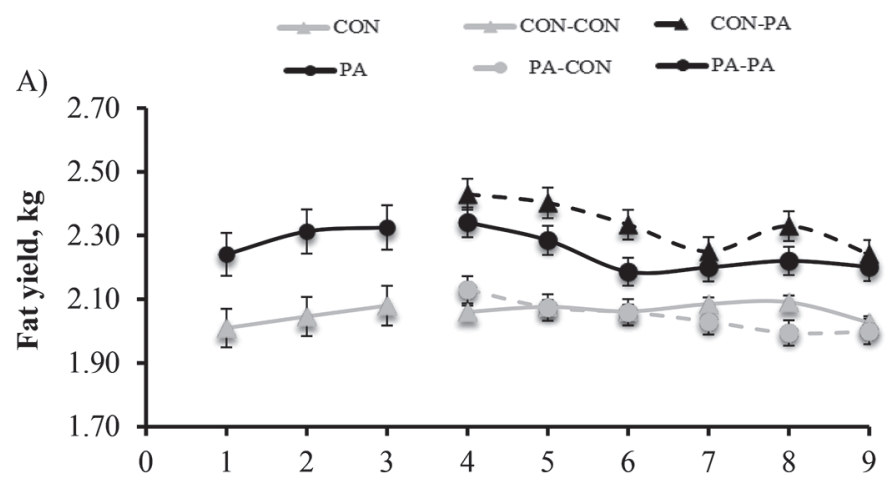

B)

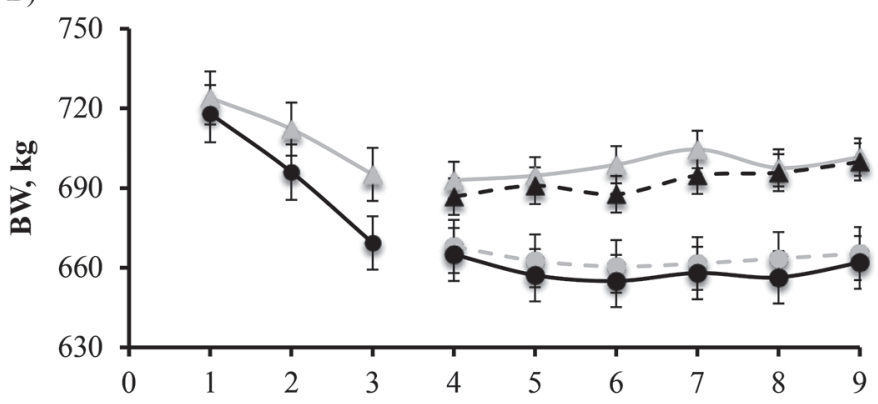

C)

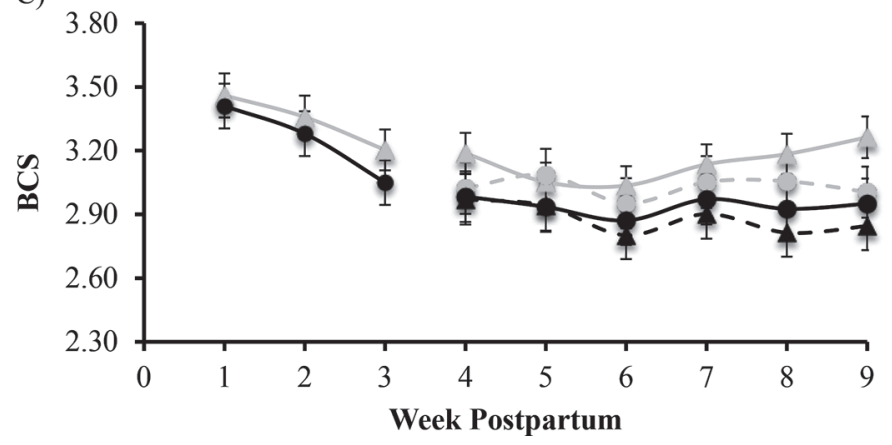

Figure 2. Effects of dietary treatments on milk fat yield (A), BW (B), and BCS (C) over time during the fresh (FR) period (1-24 DIM) and peak (PK) period (25-67 DIM). Diets fed during the FR period were either a control (CON; gray line) or $1.5 \%$ of $\mathrm{C} 16: 0$-enriched supplement (PA; black line). During the PK period treatments were as follows: $\mathrm{CON}-\mathrm{CON}=$ cows received $\mathrm{CON}$ for both $\mathrm{FR}$ and $\mathrm{PK}$ periods (gray line); $\mathrm{CON}-\mathrm{PA}=$ cows received $\mathrm{CON}$ during $\mathrm{FR}$ and changed to the PA diet (1.5\% of C16:0-enriched supplement) during the $\mathrm{PK}$ period (black dashed line); $\mathrm{PA}-\mathrm{CON}=$ cows received the $\mathrm{PA}$ diet during the FR period and changed to the CON diet during the PK period (gray dashed line); PA-PA = cows received the PA diet for the FR and PK periods (black line). During the FR period, PA increased milk fat yield $(P<0.01)$ and decreased BW $(P=0.05)$ and BCS $(P=0.04)$ compared with CON. Milk fat yield increased and BW and BCS decreased over time in both treatments (all $P<0.01$ ), and we observed a treatment $\times$ time interaction for $\mathrm{BW}(P=0.05)$ and BCS $(P=0.07)$. During PK, PA increased milk fat yield $(P<$ $0.01)$, decreased BCS $(P=0.05)$, and tended to decrease BW $(P=$ $0.06)$ compared with $\mathrm{CON}$. We did not observe a treatment $\times$ time interaction for milk fat yield $(P=0.99)$, BW $(P=0.88)$, and BCS $(P$ $=0.27)$. Error bars indicate SEM.
2007; Piantoni et al., 2015b). However, the potential response of supplemental fat during early lactation and when supplemental fat should be fed is still not well described, and previous results are inconsistent. Grummer (1992) suggested, based on studies conducted in the early 1990s, that supplemental tallow had little benefit on cow performance when fed in the first 5 to 7 wk of lactation, which is likely associated with the high levels of supplemental fat included in the diet $(5-6 \%$ DM) and reduced DMI. In contrast, recent research has increased interest in the effects of feeding individual FA, extending beyond their energy contribution to include potential metabolic and physiological effects of individual FA (Palmquist and Jenkins, 2017). Considerable research has evaluated the effects of C16:0 supplements on dairy cow performance and metabolism (e.g., Piantoni et al., 2013; de Souza and Lock, 2018); however, these studies were conducted only in postpeak cows. Therefore, our current study evaluated the effects of timing of C16:0 supplementation on production responses, whereas our companion paper discusses the effects C16:0 supplementation on nutrient digestibility, energy balance, and metabolism of early-lactation cows (de Souza et al., 2019).

Because feed intake in early postpartum is primarily controlled by mechanisms related to oxidation of fuels in the liver (Allen and Piantoni, 2013), some authors suggest that supplementing fat to cows during the immediate postpartum period may depress feed intake (Kuhla et al., 2016). The effect of fat supplements on DMI is variable and usually depends on the type of fat being fed (Rabiee et al., 2012). With postpeak cows, results from studies with highly enriched $(\geq 85 \%)$ sources of C16:0 and C18:0 have been variable, but DMI has typically not been reduced (Piantoni et al., 2013, 2015a; de Souza et al., 2016) compared with diets not supplemented with FA. In our study, feeding PA during the FR and PK periods did not reduce DMI, and the increase in DMI over time after parturition was consistent for CON and PA treatments. Similarly, feeding SFA supplements (C16:0 + C18:0) from calving to 100 DIM usually did not affect DMI in dairy cows (Jerred et al., 1990; Beam and Butler, 1998), whereas other studies feeding a similar SFA supplement reported increased DMI in cows in the immediate postpartum and early-lactation periods (Moallem et al., 2007; Piantoni et al., 2015b). Therefore, the effect of SFA supplements (C16:0 and combinations of C16:0 + C18:0) on DMI of early-lactation cows is minimal.

Interestingly, we observed that feeding PA did not affect milk yield during the immediate postpartum period (FR period), but feeding PA during the PK period increased milk yield by $3.45 \mathrm{~kg} / \mathrm{d}$ compared with CON. 


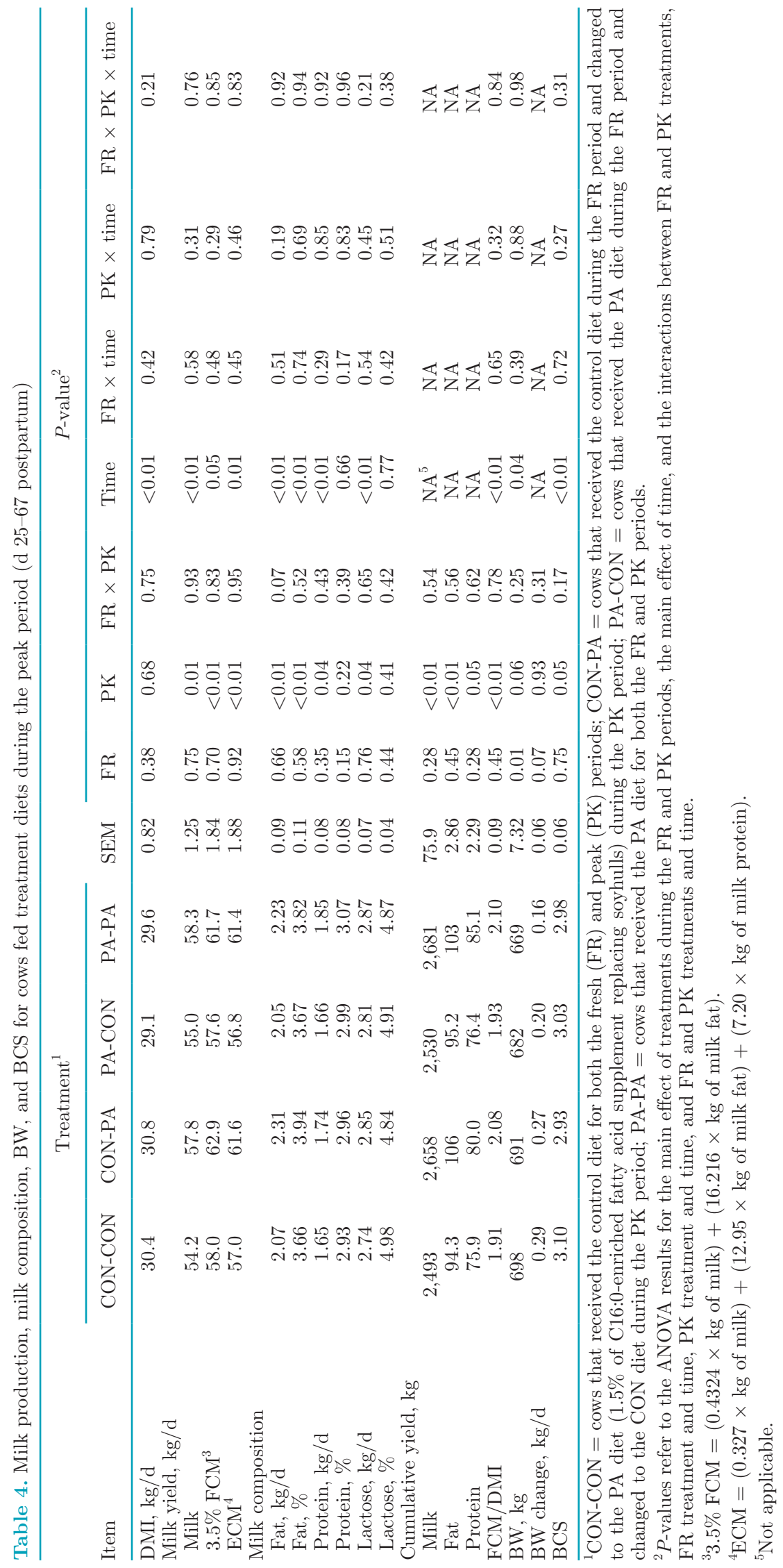


Table 5. Summation of milk fatty acid (FA) concentration and yield for cows fed treatment diets during the fresh period (d 1-24 postpartum)

\begin{tabular}{|c|c|c|c|c|c|c|}
\hline \multirow[b]{2}{*}{ Variable $^{1}$} & \multicolumn{2}{|c|}{ Treatment $^{2}$} & \multirow[b]{2}{*}{ SEM } & \multicolumn{3}{|c|}{$P$-value ${ }^{3}$} \\
\hline & $\mathrm{CON}$ & PA & & Trt & Time & Trt $\times$ time \\
\hline \multicolumn{7}{|c|}{ Summation by source, $\mathrm{g} / 100 \mathrm{~g}$ of $\mathrm{FA}$} \\
\hline De novo & 17.1 & 15.9 & 0.72 & 0.23 & $<0.01$ & 0.18 \\
\hline Mixed & 31.2 & 34.7 & 0.31 & $<0.01$ & 0.45 & $<0.01$ \\
\hline Preformed & 51.7 & 49.5 & 0.91 & 0.07 & $<0.01$ & 0.45 \\
\hline \multicolumn{7}{|c|}{ Summation by source, $\mathrm{g} / \mathrm{d}$} \\
\hline De novo & 285 & 303 & 13.5 & 0.32 & $<0.01$ & 0.98 \\
\hline Mixed & 524 & 671 & 23.3 & $<0.01$ & 0.71 & 0.12 \\
\hline Preformed & 870 & 966 & 44.5 & 0.05 & 0.42 & 0.25 \\
\hline
\end{tabular}

${ }^{1}$ De novo FA originate from mammary de novo synthesis ( $<16$ carbons), preformed FA originate from extraction from plasma ( $>16$ carbons), and mixed FA originate from both sources (C16:0 plus cis-9 C16:1). Concentrations and yields of individual FA are reported in Supplemental Tables S1 and S2 (https://doi.org/ 10.3168/jds.2018-14976), respectively.

${ }^{2}$ Diets fed during the fresh period (1-24 DIM) were either a control diet (CON) or a diet supplemented with C16:0-enriched FA supplement replacing soyhulls (PA; $1.5 \%$ of diet DM).

${ }^{3} P$-values refer to the ANOVA results for the main effect of treatment (Trt), the main effect of time, and the interaction between treatment and time.

Also, there was no interaction between the diet fed in the FR and PK periods on milk yield response, so that regardless of the diet that cows received during the FR period, PA increased milk yield when fed during the PK period. A meta-analysis by Onetti and Grummer (2004) observed that fat supplementation increased milk yield and milk fat yield when fed to cows during early lactation $(<120$ DIM) but not in mid lactation ( $>120$ DIM). However, production responses to SFA supplementation in the immediate postpartum period have been inconsistent. Beam and Butler (1998) added a SFA supplement $(\mathrm{C} 16: 0+\mathrm{C} 18: 0)$ and reported an interaction between diet and time for milk yield due to supplemental fat decreasing milk yield during the first 3 wk postpartum but increasing milk yield during the next 2 wk of the experiment. Piantoni et al. (2015b) observed that feeding a SFA supplement (C16:0 + C18:0) tended to decrease milk yield by $3.15 \mathrm{~kg} / \mathrm{d}$ in cows in the immediate postpartum period. In earlylactation cows, Weiss and Pinos-Rodríguez (2009) fed a SFA supplement (C16:0 + C18:0) to early-lactation cows (21-126 d postpartum) and observed that when diets were supplemented with SFA, energy intake was increased and directed mostly to milk yield in a lower forage diet and to body reserves in a higher forage diet. These results indicate that milk yield usually is not affected when SFA supplements are fed in the immediate postpartum period (i.e., Beam and Butler, 1998; Piantoni et al., 2015b), but milk yield may increase when these supplements are fed after 3 to 4 wk after calving (i.e., Hoffman et al., 1991; Weiss and PinosRodríguez, 2009). Our results, therefore, agree with the previous literature feeding saturated fat and with our initial hypothesis in which we postulated that the response to FA supplementation may vary due to the timing of when supplemental fat is fed.

We observed that PA increased milk fat yield during both the FR $(+280 \mathrm{~g} / \mathrm{d})$ and PK $(+210 \mathrm{~g} / \mathrm{d})$ periods but that the magnitude of response was greater during the FR period than during the PK period. Most of our short-term studies involved feeding C16:0 supplements to postpeak cows (fed at 1.5-2.0\% of diet DM) and have indicated increases in milk fat yield (Lock et al., 2013; Piantoni et al., 2013; de Souza et al., 2017). In long-term feeding, de Souza and Lock (2018) observed that feeding a C16:0 supplement (1.5\% of diet DM) over a 10-wk period increased milk fat yield by approximately $150 \mathrm{~g} / \mathrm{d}$. Although Rico et al. (2017) observed that maximum milk fat yield response occurred when C16:0 was fed at $1.5 \%$ of diet DM, the incorporation of C16:0 into milk fat increased linearly as C16:0 dose increased. Tzompa-Sosa et al. (2014) suggested that an increase in availability of C16:0 for lipid synthesis in mammary epithelial cells may increase the activity of glycerol-3-phosphate acyltransferase in the mammary gland, increasing the proportion of $\mathrm{C} 16: 0$ acylated at sn-1 that initiates triacylglycerol synthesis. Overall, the increase in milk fat associated with our PA treatment during the FR period occurred due to an increase in yield of 16-carbon milk FA by $147 \mathrm{~g} / \mathrm{d}$ (derived from both de novo synthesis and extraction from plasma) and an increase in preformed milk FA by $96 \mathrm{~g} / \mathrm{d}$. The increase in 16-carbon milk FA by PA agrees with several previous studies that fed C16:0 supplements to postpeak cows (e.g., Lock et al. 2013; Piantoni et al., 2013; de Souza et al., 2017), and the increase in preformed milk FA was likely associated with the greater BW loss for PA during the FR period. 


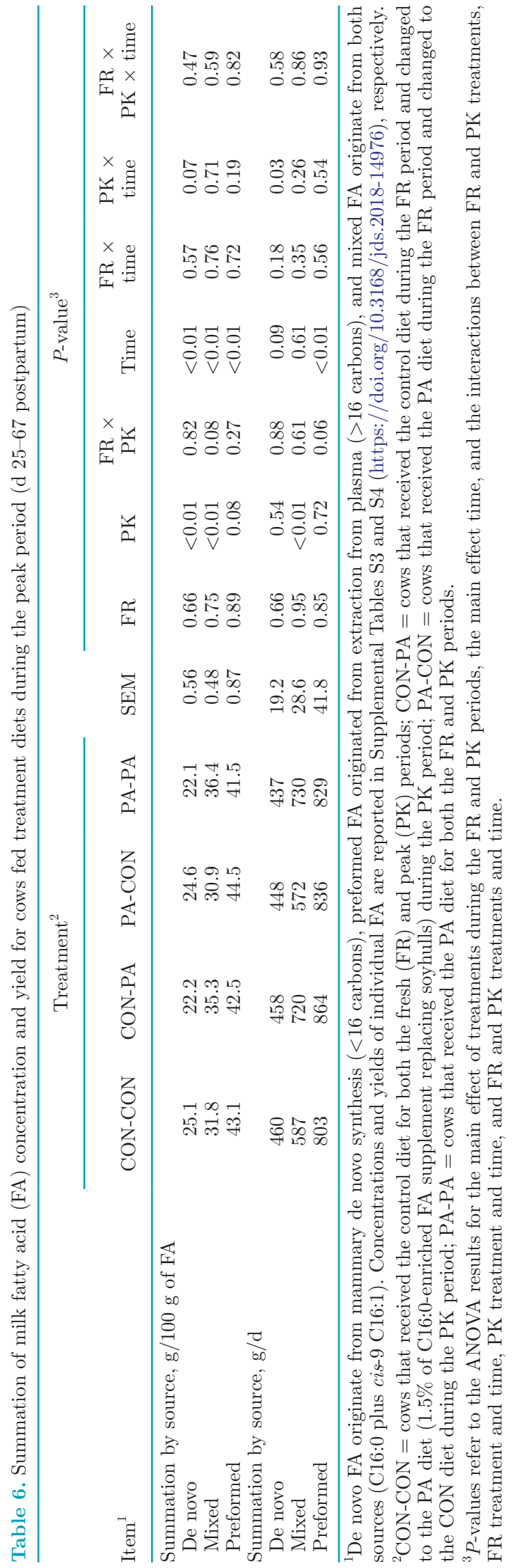

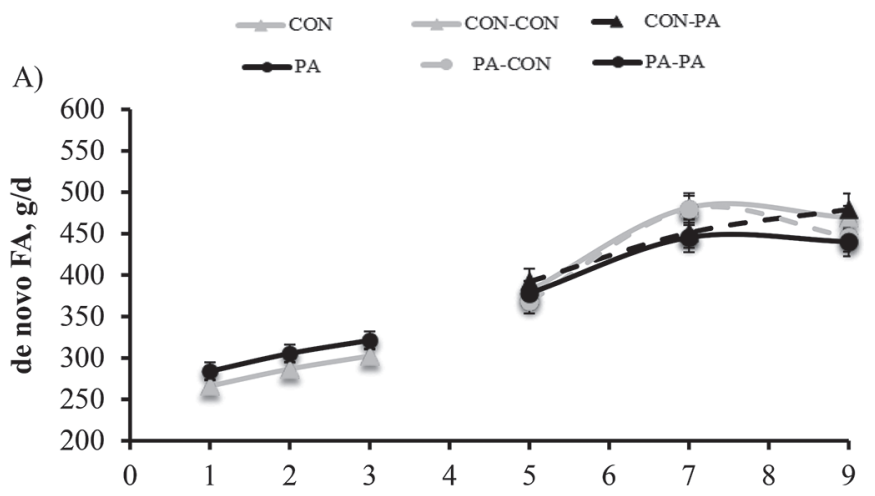

B)

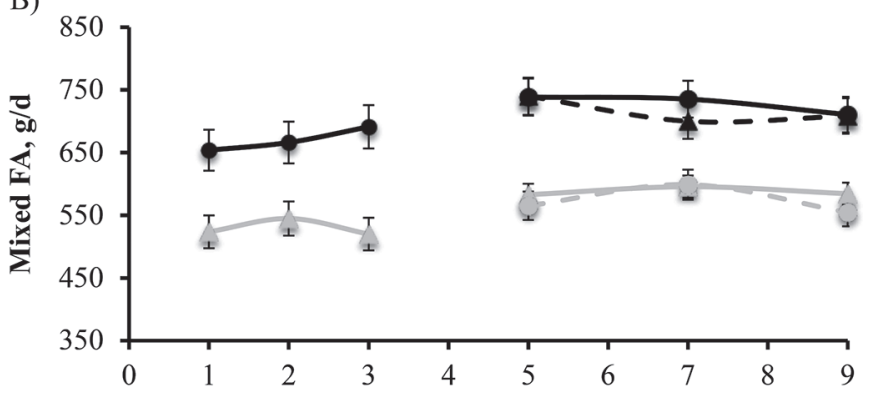

C)

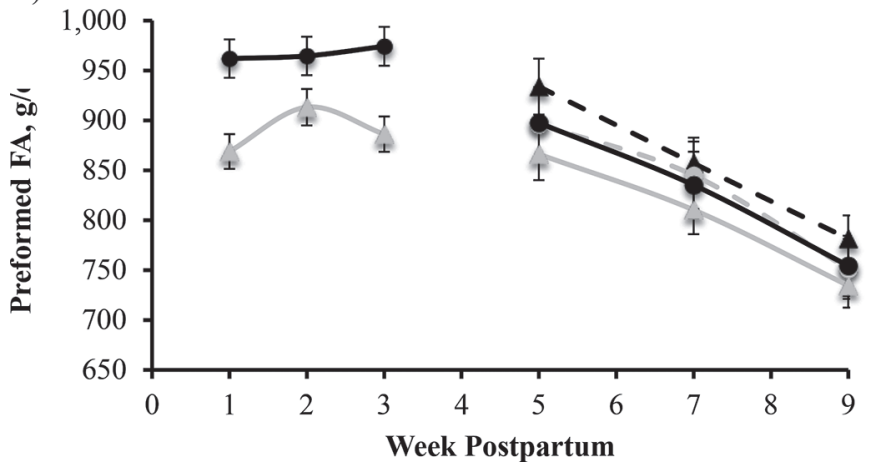

Figure 3. Effects of dietary treatments on the yield of de novo (A), mixed (B), and preformed (C) milk fatty acids (FA) over time during the fresh (FR) period (1-24 DIM) and peak (PK) period (25-67 DIM). Diets fed during the FR period were either a control (CON; gray line) or 1.5\% of C16:0-enriched supplement (PA; black line). During the PK period treatments were as follows: $\mathrm{CON}-\mathrm{CON}=$ cows received $\mathrm{CON}$ for both FR and PK periods (gray line); $\mathrm{CON}-\mathrm{PA}=$ cows received CON during FR and changed to the PA diet (1.5\% of C16:0-enriched supplement) during the PK period (black dashed line); $\mathrm{PA}-\mathrm{CON}=$ cows received the PA diet during the FR period and changed to the $\mathrm{CON}$ diet during the PK period (gray dashed line); $\mathrm{PA}-\mathrm{PA}=$ cows received the PA diet for the FR and PK periods (black line). During the FR period, PA increased mixed $(P<0.01)$ and preformed $(P=0.05)$ milk FA and did not affect de novo $(P=0.32)$ milk FA compared with CON. A tendency for a treatment $\times$ time interaction was observed for mixed $(P=0.12)$ milk FA but not for de novo $(P=0.98)$ and preformed $(P=0.25)$ milk FA. During the PK period, PA increased mixed $(P<0.01)$ milk FA and did not affect de novo $(P=0.54)$ and preformed $(P=0.72)$ milk FA compared with CON. A treatment $\times$ time interaction was observed for de novo $(P=0.03)$ milk FA but not for mixed $(P=0.26)$ and preformed $(P=0.54)$ milk FA. Error bars indicate SEM. 
Interestingly, during the PK period we observed an interaction between diet fed in the FR and PK periods for milk fat yield due to feeding PA during the PK period increasing milk fat yield to a greater extent in cows that received the CON diet $(+240 \mathrm{~g} / \mathrm{d})$ than in those that received the PA diet $(+180 \mathrm{~g} / \mathrm{d})$ during the FR period. This difference is associated with the yield of preformed FA because we observed that feeding PA during the PK period increased the yield of preformed milk FA only in cows that received the CON diet during the FR period. Overall, the yield of de novo milk FA increased and the yield of preformed milk FA decreased for all treatments as DMI increased over time. Although we did not observe treatment differences for de novo milk FA yield, the yield of C4:0 increased in both FR and PK periods when PA was fed; this is in line with our recent studies feeding C16:0 to postpeak cows (Piantoni et al., 2013; de Souza et al., 2016). It has been suggested that the increased yield of C4:0 might be part of the mechanism to maintain milk fat fluidity at body temperature, with an increase in C4:0 output due to the large diglyceride pool of highmolecular-weight FA that results from the incorporation of long-chain FA taken up from plasma (Barbano and Sherbon, 1980). Therefore, our results suggest that feeding PA during early lactation increased milk fat yield, but this is also partially related to an increase in the yield of preformed milk FA likely coming from adipose tissue.

Previous studies have observed that C16:0 supplementation increased $3.5 \%$ FCM and ECM in postpeak cows (Lock et al., 2013; Piantoni et al., 2013; de Souza et al., 2018). In our study, feeding PA during both the $\mathrm{FR}$ and PK periods increased both 3.5\% FCM and ECM, and the increase in these variables over time after parturition was consistent. Additionally, the magnitude of increase in 3.5\% FCM and ECM by PA was similar during both periods. These results are associated with the increase in the yield of milk fat and protein. In contrast, Piantoni et al. (2015b) observed that feeding a SFA supplement $(\mathrm{C} 16: 0+\mathrm{C} 18: 0)$ did not affect the yield of $3.5 \% \mathrm{FCM}$ and ECM in cows immediately postpartum (1-29 DIM), but SFA supplementation had a pronounced carryover effect (30-67 DIM), decreasing both $3.5 \%$ FCM and ECM in a low-forage diet. Also, Moallem et al. (2007) fed a SFA supplement (C16:0 + C18:0) that did not affect 3.5\% FCM or milk energy output. However, diets were fed prepartum to $100 \mathrm{~d}$ postpartum, and the effects on performance were reported as least squares means for the whole $100 \mathrm{~d}$ in lactation. Thus, the effect of fat supplementation over time on production performance cannot be discerned. Therefore, in our study the pronounced increase in ECM due to PA supplementation is associated with the potential that C16:0 supplements can increase the yield of milk fat and protein, and the ECM response is not associated with timing of C16:0 supplementation.

Although we observed that feeding PA increased ECM in early-lactation cows, it also resulted in increased BW and BCS loss. The increase in BW and BCS loss was more pronounced in the FR period than in the PK period. In the FR period, PA induced a greater decrease in BW and BCS after the second week of treatments and increased plasma levels of nonesterified fatty acids (NEFA) and reduced insulin (de Souza et al., 2019). Importantly, even though PA increased plasma NEFA concentration, NEFA levels were below the threshold considered critical for increased incidence of metabolic disorders (Ospina et al., 2013). In the PK period, the magnitude of BW and BCS loss due to PA was much smaller, and cows started recovering BW and entered positive energy balance by wk 7 (de Souza et al., 2019). Similar to our results, Moallem et al. (2007) observed that feeding a SFA supplement $(\mathrm{C} 16: 0+\mathrm{C} 18: 0)$ increased milk yield but also increased BCS loss compared with a control diet. In contrast, Piantoni et al. (2015b), feeding a SFA supplement (C16:0 + C18:0), observed that regardless of dietary forage content, FA supplementation decreased BW loss and tended to decrease BCS loss in cows during the immediate postpartum period (1-29 DIM); however, this was at the expense of milk production. With postpeak cows, Mathews et al. (2016) observed a decrease in glucosestimulated NEFA disappearance in cows fed C16:0, suggesting the possibility of localized adipose tissue insulin resistance with prolonged $\mathrm{C} 16: 0$ supplementation. Because the development of insulin resistance in adipose and skeletal muscle tissues enables the dairy cow to partition nutrients toward the mammary gland during early lactation (Bell, 1995; Bell and Bauman, 1997), we postulate that the change in energy partitioning to milk at the expense of body reserves in the immediate postpartum period in PA-treated cows may in part be related to changes in insulin resistance. The potential role of individual FA on nutrient partitioning to support lactation and its mechanisms requires further investigation.

To our knowledge, few studies have been designed to evaluate the effects of timing of FA supplementation on production responses of dairy cows. Holter and Hayes (1994) evaluated the timing of feeding a Ca salts of palm FA supplement (3.75\% diet DM) starting at 1, 29, and 57 DIM up to 112 DIM on production responses of dairy cows. The authors reported that most production responses, including DMI, milk yield, and $4 \%$ FCM, were not affected by timing of supplementation. In contrast, milk fat content decreased as the time of supplement introduction to the diet increased. In our 
study, although the increase in milk energy output with PA was similar in the FR and PK periods (de Souza et al., 2019), changes in body reserves were affected by the time of supplementation, with cows decreasing BW due to PA to a greater extent in the FR period. Increased rates of lipolysis and BW loss in the immediate postpartum period are expected because dairy cows exhibit this propensity to nurture the neonate from tissue reserves (Bauman and Currie, 1980). However, prolonged negative energy balance and increased BW loss may negatively affect reproduction (Roche et al., 2009). A negative association between BCS loss in early lactation and reproduction is associated with delayed ovarian activity, infrequent luteinizing hormone pulses, poor follicular response to gonadotropins, and reduced functional competence of the follicle (Chagas et al., 2007). Although there is general agreement regarding the importance of energy stores and energy balance on reproduction, some inconsistencies in this relationship also occur (Roche et al., 2009). For instance, feeding a Ca salts of palm FA supplement (2.6\% diet DM) from parturition to 120 DIM increased milk yield and BW loss in dairy cows but also increased plasma progesterone and pregnancy rate (Sklan et al., 1991). In contrast, Sklan et al. (1994) observed that feeding a Ca salts of palm FA supplement (2.5\% of diet DM) from parturition to 120 DIM increased milk yield and BW loss in multiparous and primiparous cows, whereas reduced conception rate at first insemination occurred only in primiparous cows. Further studies are needed to understand the mechanism by which C16:0 supplementation increases milk energy output at the expense of body reserves in the immediate postpartum period and the possible effects of greater BW and BCS losses on health and reproduction of dairy cows.

\section{CONCLUSIONS}

Feeding a C16:0 supplement to early-lactation cows consistently increased the yield of ECM in both the FR and $\mathrm{PK}$ periods compared with a control diet. For some variables, the effect of feeding C16:0 was affected by timing of supplementation because milk yield increased only during the PK period and $\mathrm{BW}$ decreased to a greater extent in the FR period when C16:0 supplement was fed. Regardless of diet fed during the FR period, feeding a C16:0 supplement during the PK period increased yield of milk and milk components.

\section{ACKNOWLEDGMENTS}

We acknowledge Global Agri-Trade Corporation (Rancho Dominguez, CA) for financial support of this study. We also acknowledge R. J. Tempelman (Department of Animal Science, Michigan State University, East Lansing) for the helpful discussion about statistical analysis and Stacy Nichols (Vita Plus, Madison, WI) for the helpful discussion about diet formulation. We acknowledge C. L. Preseault, L. N. Worden, J. Guy, Y. Sun, S. Schmidt, and M. Western (all in the Department of Animal Science, Michigan State University) and the staff of the Michigan State University Dairy Cattle Teaching and Research Center for their assistance in this experiment. Jonas de Souza was supported by a $\mathrm{PhD}$ fellowship from Coordenação de Aperfoiçamento de Pessoal de Nivel Superior (CAPES) from the Brazilian Ministry of Education (Brasilia, DF, Brazil).

\section{REFERENCES}

Allen, M. S. 2000. Effects of diet on short-term regulation of feed intake by lactating dairy cattle. J. Dairy Sci. 83:1598-1624.

Allen, M. S., B. Bradford, and M. Oba. 2009. Board-invited review: The hepatic oxidation theory of the control of feed intake and its application to ruminants. J. Anim. Sci. 87:3317-3334.

Allen, M. S., and P. Piantoni. 2013. Metabolic control of feed intake: Implications for metabolic disease of fresh cows. Vet. Clin. North Am. Food Anim. Pract. 29:279-297.

AOAC. 1990. Official Methods of Analysis. 15th ed. Vol. 2. AOAC Int., Arlington, VA.

Barbano, D. M., and J. W. Sherbon. 1980. Polyunsaturated protected lipid: Effect on triglyceride molecular weight distribution. J. Dairy Sci. 63:731-740.

Bauman, D. E., and W. B. Currie. 1980. Partitioning of nutrients during pregnancy and lactation: A review of mechanisms involving homeostasis and homeorhesis. J. Dairy Sci. 63:1514-1529.

Beam, S. W., and W. R. Butler. 1998. Energy balance, metabolic hormones, and early postpartum follicular development in dairy cows fed prilled lipid. J. Dairy Sci. 81:121-131.

Bell, A. W. 1995. Regulation of organic nutrient metabolism during transition from late pregnancy to early lactation. J. Anim. Sci. 73:2804-2819.

Bell, A. W., and D. E. Bauman. 1997. Adaptations of glucose metabolism during pregnancy and lactation. J. Mammary Gland Biol. Neoplasia 2:265-278.

Boerman, J. P., J. de Souza, and A. L. Lock. 2017. Milk production and nutrient digestibility responses to increasing levels of stearic acid supplementation of dairy cows. J. Dairy Sci. 100:2729-2738.

Chagas, L. M., J. J. Bass, D. Blache, C. R. Burke, J. K. Kay, D. R. Lindsay, M. C. Lucy, G. B. Martin, S. Meier, F. M. Rhodes, J. R. Roche, W. W. Thatcher, and R. Webb. 2007. Invited review: New perspectives on the roles of nutrition and metabolic priorities in the subfertility of high-producing dairy cows. J. Dairy Sci. 90:4022-4032.

de Souza, J., J. L. Garver, C. L. Preseault, and A. L. Lock. 2017. Effects of prill size of a palmitic acid-enriched fat supplement on yield of milk and milk components and nutrient digestibility of dairy cows. J. Dairy Sci. 100:379-384.

de Souza, J., and A. L. Lock. 2018. Long-term palmitic acid supplementation interacts with parity in lactating dairy cows: Production responses, nutrient digestibility, and energy partitioning. J. Dairy Sci. 101:3044-3056.

de Souza, J., C. L. Preseault, and A. L. Lock. 2016. Short communication: Lactational responses to palmitic acid supplementation when replacing soyhulls or dry ground corn. J. Dairy Sci. 99:1945-1950.

de Souza, J., C. L. Preseault, and A. L. Lock. 2018. Altering the ratio of dietary palmitic, stearic, and oleic acids in diets with or without 
whole cottonseed affects nutrient digestibility, energy partitioning, and production responses of dairy cows. J. Dairy Sci. 101:172-185.

de Souza, J., C. Strieder-Barboza, G. A. Contreras, and A. L. Lock. 2019. Effects of timing of palmitic acid supplementation during early lactation on nutrient digestibility, energy balance, and metabolism of dairy cows. J. Dairy Sci. 102:274-287. https://doi.org/ 10.3168/jds.2018-14977.

Goering, H. K., and P. J. Van Soest. 1970. Forage Fiber Analysis (Apparatus, Reagents, Procedures, and Some Applications). Agricultural Handbook No. 379. ARS-USDA, Washington, DC.

Grummer, R. R. 1992. Feeding strategies for supplemental fat. Pages 248-259 in Large Dairy Herd Management. H. H. Van Horn and C. J. Wilcox, ed. ADSA, Champaign, IL.

Harvatine, K. J., J. W. Perfield, and D. E. Bauman. 2009. Expression of enzymes and key regulators of lipid synthesis is upregulated in adipose tissue during CLA-induced milk fat depression in dairy cows. J. Nutr. 139:849-854.

Hoffman, P. C., R. R. Grummer, R. D. Shaver, G. A. Broderick, and T. R. Drendel. 1991. Feeding supplemental fat and undegraded intake protein to early lactation dairy cows. J. Dairy Sci. 74:3468-3474.

Holter, J. B., and H. H. Hayes. 1994. No advantage to delaying the introduction of calcium soaps of palm oil fatty acids to early lactation dairy rations. J. Dairy Sci. 77:799-812.

Jerred, M. J., D. J. Carrol, D. K. Combs, and R. R. Grummer. 1990. Effects of fat supplementation and immature alfalfa to concentrate ratio on lactation performance of dairy cattle. J. Dairy Sci. $73: 2842-2854$.

Kuhla, B., C. C. Metges, and H. M. Hammon. 2016. Endogenous and dietary lipids influencing feed intake and energy metabolism of periparturient dairy cows. Domest. Anim. Endocrinol. 56:S2-S10.

Lock, A. L., C. L. Preseault, J. E. Rico, K. E. DeLand, and M. S. Allen. 2013. Feeding a C16:0-enriched fat supplement increased the yield of milk fat and improved feed efficiency. J. Dairy Sci. 96:6650-6659

Mathews, A. T., J. E. Rico, N. T. Sprenkle, A. L. Lock, and J. W. McFadden. 2016. Increasing palmitic acid intake enhances milk production and prevents glucose-stimulated fatty acid disappearance without modifying systemic glucose tolerance in mid-lactation dairy cows. J. Dairy Sci. 99:8802-8816.

McCarthy, M. M., T. Yasui, C. M. Ryan, G. D. Mechor, and T. R. Overton. 2015. Performance of early-lactation dairy cows as affected by dietary starch and monensin supplementation. J. Dairy Sci. 98:3335-3350.

Moallem, U., M. Katz, A. Arieli, and H. Lehrer. 2007. Effects of peripartum propylene glycol or fats differing in fatty acid profiles on feed intake, production, and plasma metabolites in dairy cows. J. Dairy Sci. 90:3846-3856.

National Research Council. 2001. Nutrient Requirements of Dairy Cattle. 7th rev. ed. National Academy Press, Washington, DC.

Onetti, S. G., and R. R. Grummer. 2004. Response of lactating cows to three supplemental fat sources as affected by forage in the diet and stage of lactation: A meta-analysis of literature. Anim. Feed Sci. Technol. 115:65-82.

Ospina, P. A., J. A. McArt, T. R. Overton, T. Stokol, and D. V. Nydam. 2013. Using nonesterified fatty acids and $\beta$-hydroxybutyrate concentrations during the transition period for herd-level monitoring of increased risk of disease and decreased reproductive and milking performance. Vet. Clin. North Am. Food Anim. Pract. $29: 387-412$.

Palmquist, D. L., and T. C. Jenkins. 2017. A 100-year review: Fat feeding of dairy cows. J. Dairy Sci. 100:10061-10077.

Piantoni, P., A. L. Lock, and M. S. Allen. 2013. Palmitic acid increased yields of milk and milk fat and nutrient digestibility across production level of lactating cows. J. Dairy Sci. 96:7143-7154.

Piantoni, P., A. L. Lock, and M. S. Allen. 2015a. Milk production responses to dietary stearic acid vary by production level in dairy cattle. J. Dairy Sci. 98:1938-1949.

Piantoni, P., A. L. Lock, and M. S. Allen. 2015b. Saturated fat supplementation interacts with dietary forage neutral detergent fiber content during the immediate postpartum and carryover periods in Holstein cows: Production responses and digestibility of nutrients. J. Dairy Sci. 98:3309-3322.

Rabiee, A. R., K. Breinhild, W. Scott, H. M. Golder, E. Block, and I. J. Lean. 2012. Effect of fat additions to diets of dairy cattle on milk production and components: A meta-analysis and metaregression. J. Dairy Sci. 95:3225-3247.

Rico, D. E., Y. Ying, and K. J. Harvatine. 2014a. Effect of a highpalmitic acid fat supplement on milk production and apparent total-tract digestibility in high- and low-milk yield dairy cows. J. Dairy Sci. 97:3739-3751.

Rico, J. E., M. S. Allen, and A. L. Lock. 2014b. Compared with stearic acid, palmitic acid increased the yield of milk fat and improved feed efficiency across production level of cows. J. Dairy Sci. 97:1057-1066.

Rico, J. E., J. de Souza, M. S. Allen, and A. L. Lock. 2017. Nutrient digestibility and milk production responses to increasing levels of palmitic acid supplementation vary in cows receiving diets with or without whole cottonseed. J. Anim. Sci. 95:436-446.

Roche, J. R., N. C. Friggens, J. K. Kay, M. W. Fisher, K. J. Stafford, and D. P. Berry. 2009. Invited review: Body condition score and its association with dairy cow productivity, health, and welfare. J. Dairy Sci. 92:5769-5801.

Rodney, R. M., P. Celi, W. Scott, K. Breinhild, and I. J. Lean. 2015. Effects of dietary fat on fertility of dairy cattle: A meta-analysis and meta-regression. J. Dairy Sci. 98:5601-5620.

Sklan, D., M. Kaim, U. Moallem, and Y. Folman. 1994. Effect of dietary calcium soaps on milk yield, body weight, reproductive hormones, and fertility in first parity and older cows. J. Dairy Sci. $77: 1652-1660$.

Sklan, D., U. Moallem, and Y. Folman. 1991. Effect of feeding calcium soaps of fatty acids on production and reproductive responses in high producing lactating cows. J. Dairy Sci. 74:510-517.

Tzompa-Sosa, D. A., G. A. van Aken, A. C. M. van Hooijdonk, and H. J. F. van Valenberg. 2014. Influence of C16:0 and long-chain saturated fatty acids on normal variation of bovine milk fat triacylglycerol structure. J. Dairy Sci. 97:4542-4551.

Weiss, W. P., and J. M. Pinos-Rodríguez. 2009. Production responses of dairy cows when fed supplemental fat in low- and high-forage diets. J. Dairy Sci. 92:6144-6155.

Wildman, E. E., G. M. Jones, P. E. Wagner, R. L. Boman, H. F. Troutt Jr., and T. N. Lesch. 1982. A dairy cow body condition scoring system and its relationship to selected production characteristics. J. Dairy Sci. 65:495-501. 